\title{
Bank Borrowers and Loan Sales: New Evidence on the Uniqueness of Bank Loans
}

\author{
Sandeep Dahiya ${ }^{2}$, Manju Puri ${ }^{3}$, Anthony Saunders
}

July 2000

\begin{abstract}
This paper examines the information content of the announcement of the sale of a borrower's loan by its bank. A large body of research has documented the positive impact on a firm's stock price around the announcement of formation and renewal of bank lending relationships. In light of these findings it would seem natural that when a bank chooses to sell off its loans, the stock returns of the borrower would be adversely affected. Our paper is the first study to test this hypothesis. We find that the stock returns of these borrowers are significantly negatively impacted on average for the period surrounding the announcement of a loan sale. The post-loan sale period is also marked by a large incidence of bankruptcy filings by the borrowers whose loans are sold. Overall, the evidence supports the hypothesis that the news of a bank loan sale has a negative certification impact, which is validated by the subsequent performance of the firm whose loan is sold. We conduct similar event study tests for those banks that engage in loan sales and find that the stock returns of the selling banks are not significantly impacted on average. Cross-sectional tests reveal that loan sales were made by banks that emphasized trading income and had relatively large Commercial and Industrial loan portfolios. For our sample period, a bank's capital adequacy position did not appear to have a material effect on a bank's decision to sell its loans.
\end{abstract}

JEL classification: G14, G21

Keywords: Loan sales, Lending relationship, Commercial banks.

\footnotetext{
* McDonough School of Business, Georgetown University, G-04 Old North, Washington DC 20057. Tel. (202) 687 3832, Email: sd@msb.edu

${ }^{\dagger}$ Graduate School of Business, Stanford University, Stanford, CA 94305, Tel: (650) 723 3402, Email: mpuri@gsb.stanford.edu

Stern School of Business, New York University, 44 West $4^{\text {th }}$ Street, New York, NY 10012, Tel: (212) 998

0711, Email: asaunder@stern.nyu.edu

We would like to thank Linda Allen for helpful comments.
} 
"An original lender on a $\$ 150$ million Bradlees credit reportedly sold a $\$ 5$ million piece of the revolver in a hurry last week, according to traders familiar with the situation, sending the message to some traders that the lenders most familiar with Bradlees are not comfortable with the company's situation. Because a long-term lender dumped the paper, and urgently, traders said they suspect the lender knew something they did not."

-Bank Letter dated 6/19/1995

\section{Introduction}

The secondary loan market for loans has been growing in recent times. While a number of reasons for loan sales have been identified in the previous literature, ${ }^{1}$ there have been no empirical studies of the effects of such sales on the returns of those bank borrowers whose loans are sold or on the banks selling loans.

Conventional wisdom has long held that loan sales by banks -- especially loans of customers who have established long-term customer relationships with that bank -- would have a negative information effect regarding the borrowing firm. This effect would result from the special or unique role of banks ${ }^{2}$ as "insiders" to the borrower firms, such that a decision to sell a customer's loan would be taken as revealing to the market hitherto private (negative) information regarding a borrower's financial condition. Indeed, while the effect of loan sales on borrowers has been untested prior to this paper, such an effect might be expected given the findings of James (1987), Lummer and McConnell (1989), Best and Zhang (1993), Billett, Flannery and Garfinkel (1995) among others, that new loans and loan renewals carry (positive) private information to the outside equity market about a borrowing firm's financial condition. ${ }^{3}$ Indeed, in a recent paper, James and

\footnotetext{
${ }^{1}$ See for example Pennacchi (1988) and James (1988) who model the effects of loan sales on a bank's capital position and its underinvestment problem.

${ }^{2}$ The special information producing and monitoring functions of banks have been discussed by Campbell and Kracaw (1980), Diamond (1984) and Fama (1985).

${ }^{3}$ James (1987) finds a significant positive impact of announcement of bank loan agreements; Lummer and McConnell (1989) document a positive impact of favorable loan renewals while non-renewals are accompanied by negative returns for the borrowers. Billet, Flannery, and Garfinkel (1995) show that the impact of loan announcements is positively related to the quality of the lender. Best and Zhang (1993) document evidence that the stock market reaction is strongest for those borrowers where the quality of
} 
Smith (2000) provide a comprehensive review of the past and recent research on the special nature of bank loan financing. Overall, they show that research to date finds a robust, favorable, impact of bank loan announcements on borrowers' stock returns in contrast to the insignificant or negative response of investors to the announcement of most other forms of new security issuance (e.g. public debt and equity).

While the positive impact of news announcing the formation of a bank lending relationship is well established, there is a paucity of studies examining the impact of the termination of a banking relationship on a borrower's stock returns. ${ }^{4}$ In this paper we employ a previously unutilized information source to identify loan sale events and test the effects of such sales on borrowers. We conduct two tests. First, we test for and find a significant negative impact of loan sale announcements on the stock returns of borrowers, which is a mirror image of the established finding that the announcement of new lending relationships (or their continuation) have a positive effect on a borrower's stock returns. Our finding is both consistent with and extends the existing literature on this dimension. Second, we examine if the negative information contained in the loan sale announcement is validated in the long-term performance of firms whose loans are sold. We find that almost half of these firms file for bankruptcy within three years of the loan sale announcement.

We are also interested in the factors that influence a bank's decision to sell its loans. One possibility identified in the theoretical literature is that bank loan sales are motivated by a bank's desire to mitigate "regulatory taxes" such as capital requirements. (see, for example, Pennacchi (1988)). Moreover, loan sales may reflect the loan origination and

publicly available information is the poorest. Related to this evidence, Puri (1996), and Gande, et. al (1997), find a positive effect for the prices of new securities when the bank is both the lender and underwriter, suggesting that the bank's certification role exists even in situations where there may be confounding effects due to the bank's multiple roles.

${ }^{4}$ Slovin, Shuska and Polonchek (1993) examine the impact of possible termination of lending relationships by examining the stock returns of borrowers of Continental Illinois Bank during the bank's financial problems. Dahiya (2000) examines the impact of borrower distress on the lending bank when the lending relationship is likely to terminate following announcement of default or bankruptcy filing by the borrower of the bank. 
distribution abilities of a bank. Consequently, we examine the motivation for a bank to sell loans as well as the effect of a loan sale announcement on the selling bank's equity returns. While cross sectional tests over our sample period revealed no significant relationship between a bank's probability of selling a loan and its capital adequacy position, the probability of a bank selling a loan does appear to be positively related to the size of the bank's commercial and industrial loan portfolio as well as its trading income as a proportion of its assets. Finally, on average, loan sales appear to have had little direct (net) impact on a bank's equity return.

The outline of the paper is as follows: Section 2 discusses data sources and sample selection. Section 3 presents the results of the tests relating the effects of loan sales on borrower returns and the long run viability of the firm. Section 4 presents tests analyzing the effects of loan sales on selling banks' returns and characteristics. Section 5 is a summary and conclusion.

\section{Data and sample selection}

The bank loan sales market is an over-the-counter, wholesale market in which transactions are arranged through a network of dealers. Historically, trades took many weeks to complete, however, dealers now work for completion of trades with a $\mathrm{T}+10$ day horizon. ${ }^{5}$ Typical sellers of bank loans are large wholesale money center (e.g. Citibank) and overseas banks (e.g. ING Barings). Typical buyers of bank loans are smaller regional banks, foreign banks, vulture funds (including hedge funds) as well as insurance companies. (See, for example, Miller (1998)). Key sources of information about the market are trade newsletters and screen services such as Bloomberg that list and identify loan sales. In our study we use one market newsletter, Bank Letter, to identify the

\footnotetext{
${ }^{5}$ Interviews with loan traders reveal an increased standardization in the custody, settlement and payment procedures surrounding loan sales in recent years.
} 
secondary market sale of a bank loan by one of the original lenders. Bank Letter is a weekly publication, and from our discussions with traders is one of the most widely followed newsletters in the secondary loan market. ${ }^{6}$

As a first step in developing a sample of loan sales, all announcements of loan sales published in Bank Letter for the period 1994 to 1998 were tabulated. This step yielded a total of 107 loan sale announcements, including some sales of loans of non-US borrowers. This list also included multiple sale announcements for the same borrower. For example, there were 11 separate loan sale announcements for Mobilemedia in the period 8/12/96 to $8 / 18 / 97$. We then searched the CRSP daily price database for a match to those firms whose loans had been sold, so as to determine the availability of an equity price history around the date of announcement of a loan sale. This procedure yielded a final sample of 29 firms for which a total of 57 loan announcements were reported in Bank Letter.

As a second step we conducted an event study on the whole sample of 57 loan sale announcements to examine the impact of such announcements on a borrower's stock return. To get a better understanding of how multiple announcements of loan sales (if any), for the same borrower, affected a borrower's stock price, we also conducted an event study for the first loan sale announcement, second loan sale announcement and third loan sale announcement of loans of the same borrower.

In order to examine the operating performance of the firms in the period before the loan sale was made we compute financial characteristics (performance measures) of these firms using data for the year prior to the year in which the loan sale took place. In particular, we calculate a borrowing firm's return on assets by dividing EBITDA (Compustat data item \# 13) by the book value total assets (Compustat data item \# 6), total

\footnotetext{
${ }^{6}$ Bank Letter has recently been renamed as Loan Market Week. It is published by Institutional Investor, Inc., which publishes a number of other well-known newsletters such as Bond Week, Derivatives Week and Corporate Financing Week.
} 
leverage, computed by dividing book value of current liabilities and long term debt (sum of Compustat item \# 5 and \# 9) by the book value of total assets, and investment intensity, which is the ratio of capital expenditure (Compustat data item \# 128) divided by book value of total assets.

The borrowing firms whose loans were sold come from a number of industries; in order to account for industry wide effects we adjust each borrowing firm's performance measures by median industry performance. For example, to calculate the industryadjusted return on assets we calculate this ratio for all firms in the Compustat files that have the same 2-digit SIC code as the sample firm and take the median of these ratios. This median return on assets for the industry is then subtracted from the return on assets for the sample firm (for the same year). This procedure is carried out for all 29 firms whose loans were sold so as to compute the industry-adjusted return on assets for every firm in the sample.

To analyze the long-term performance of the sample of loan sale firms (in the postloan sale period) we focus on the survival rate of these firms after an announcement of sale of their loan is made. To determine if any of the 29 firms in our sample filed for bankruptcy after a bank announced the sale of a firm's loan we follow a two step procedure. As a first step we match all the firms whose loanswere sold against the list of firms filing for Chapter 11 in the Bankruptcy Datasource. ${ }^{7}$ This step allowed us to identify the firms that went bankrupt subsequent to the loan sale announcement. As a second step, we searched the Dow Jones News Retrieval Service for any stories that contained the sample firm's name and the words "Chapter 11" or "bankruptcy" to confirm if the news of the bankruptcy was reported in the public media. This step is a robustness check to ensure that we identify all firms that file for bankruptcy after a loan sale.

\footnotetext{
${ }^{7}$ The Bankruptcy Datasource is a database produced by New Generation Research, Boston. It is available through Securities Data Corporation as well as Lexis-Nexis. It is a comprehensive source of data on Chapter 11 filings (since 1988) by all firms that have public securities (debt and/or equities) outstanding and have more than 10 million in assets. All the 29 firms in our sample meet these criteria.
} 


\section{Test methodology and results}

We employ the event study methodology of Dodd and Warner (1983) to estimate the impact of a bank loan sale announcement on the stock return of the borrowing firm. ${ }^{8}$ The abnormal returns are computed using the market model. The parameters of the market model are estimated by regressing the firm's common stock returns for the period 200 days before the event date (defined as the date of publication of Bank Letter announcing the loan sale) to 50 days before the event date on the rate of return on CRSP's dividend inclusive, value-weighted index for NYSE/AMEX/Nasdaq stocks. The abnormal return is computed as the difference between the observed return and the estimated return from the market model. Cumulative abnormal return (CAR) is the sum of abnormal returns for the days in the relevant event window.

The results for the event study are reported in Table 1. Panel A reports the cumulative abnormal returns (CAR) for the entire sample of 57 loan sale announcements. Panel B, Panel C and panel D, respectively, focus on the impact of the first loan sale announcement and any subsequent second and third announcements of the sale of loans of the same borrower. As can be seen, for various event windows (11 days, 7 days, 5 days and 3 days) the results reported in Table 1 provide strong evidence of a negative news effect surrounding a bank loan sale announcement. From Table 1, Panel A, for a 3 day window surrounding the full sample of 57 loan sale announcements, the abnormal return for the borrowers whose loans were sold are on average $-4.6 \%$, significant at the $1 \%$ level. Moreover, as shown in panels $\mathrm{B}, \mathrm{C}$, and $\mathrm{D}$, this abnormal return effect is not

\footnotetext{
${ }^{8}$ For firms with multiple loan sale announcements there is an empirical issue of what estimation period should be used to obtain parameters of the market model. We use a 150-day period starting 200 days before the event date to 50 days before the event date as the estimation period. For the firms with multiple announcements the estimation period of sales after the first announcement may overlap with the event window of the preceding loan sale. For these firms we use the 150-day period before the first announcement to market model parameters and use these for subsequent announcements. The results are essentially unchanged if we do not use this modification and treat each announcement as an independent announcement.
} 
only significant for the first loan sale announcement but also for the second. The third loan sale announcement, for the same borrowers, shows mixed results and is based on a very small sample of loan sales $(\mathrm{N}=7)$. Overall, these results are consistent with a bad news (information) effect arising from loan sales of any given borrower's loans, i.e., the converse of the good news effect of new loan announcements or renewals (see, James (1987), for example).

Table 2 focuses on the first announcement (29 out of 57) of a loan sale. For our sample of 29 firms, we find an average abnormal return of $-1.738 \%$ for borrowers for the 3-day window around the day that the news of a bank loan sale is announced, significant at the $1 \%$ level (see also Table 1, panel B).

Our next test comprises of examining whether the negative information that the market surmises from the loan sale announcement is validated by the borrowing firm's subsequent performance. If the market perceives that the bank's inside information about the firm's future prospects is unfavorable since the bank has decided to sell the loan rather than continue its lending relationship with the firm at its current level, then a logical consequence would be that such firms should see a decline in their performance subsequent to the loan sale.

Perhaps the starkest and simplest measure of poor performance is whether or not a firm goes bankrupt. We collect data on if and when a firm filed for bankruptcy under Chapter 11 of the U.S. Bankruptcy code over a period of three years from the date of the loan sale announcement. We find that a large number of our sample firms (close to half of the firms for whom loan sales occurred) file for bankruptcy within three years from the date of the loan sale announcement. Table 3 shows that $28 \%$ of these firms filed for bankruptcy within a year of the bank loan sale announcement, an additional $10 \%$ within two years, and a further $7 \%$ within three years. In aggregate, $45 \%$ of our sample firms filed for bankruptcy within three years of their loan being announced for sale. 
These results of subsequent poor performance, combined with our results of the negative stock price reaction at the time of the loan sale announcement, are consistent with the role of banks as monitors (or corporate insiders) and the uniqueness of bank loans in conveying hitherto private information to the capital market at large.

A natural question, however, is whether the ex-post performance of these firms is correlated to their ex-ante performance prior to the loan sale, i.e., whether we could have anticipated the poor performance of these firms even without the announcement of the sale of a loan. Related to this is the question: what are the (publicly available) financial characteristics of those firms whose loans are sold at the time of the loan sale? To answer this question, we collate information on the financial characteristics of those firms whose loans are sold in the most recent year prior to the loan sale.

Table 4 provides some financial and operating performance measures for the sample of borrowing firms whose loans were sold over the 1994-1998 period. These performance measures are for the year prior to the year in which the loan sale was reported in Bank Letter, and are reported on an industry adjusted (median) basis. Specifically, financial ratios were calculated for all firms with the same 2-digit SIC code as that of borrowing firm whose loan was sold and the median financial ratio (for the industry) was then subtracted from the financial ratio of the borrowing firm. Three such financial ratios are reported in Table 4. It can be seen that firms whose loans were sold appear to have performed below the industry median in the year preceding the loan sale. In particular, they had a lower return on assets, a higher level of debt (as measured by the ratio of book liabilities to total assets) and a lower degree of investment intensity (measured by capital expenditures to total assets) compared to the median firm in the same industry.

Nevertheless, we want to examine further whether these are the poorest performing firms in their industry, i.e., whether, on an ex-ante basis, we would have expected these firms to have little future viability. For example, if our loan sale sample firms were in the 
bottom 5 percentile of their industry, one might anticipate that some of these firms would go bankrupt and/or exit the industry. Table 5 compares the financial performance of the sample of 29 firms, whose loans were sold, to their respective peer industry groups. Specifically, for the year immediately preceding the loan sale announcement, we calculate a set of financial ratios (as publicly available proxy measures of performance), for all firms that have the same 2-digit SIC codes as each borrower whose loan was sold. This allows us to generate a distribution for each financial ratio within the loan sale firm's industry. Surprisingly we find that the firms whose loans are sold are not the worst performers in their respective industries nor are they concentrated in the bottom decile or even the bottom $25 \%$ (quartile). As Table 5 shows, for proxies such as return on assets, the majority of the sample firms lie in the 25 to 50 percentile. This suggests that publicly available financial information alone may have been insufficient for investors to clearly distinguish, or pre-identify, the degree of weakness of the firms whose loans were sold and that publicly announced loan sale decisions by banks appear to have provided valuable (hitherto private) information to outside investors regarding the true financial condition of these firms.

To further corroborate these results we create a control group of a matched sample of 29 firms that had a loan outstanding, but for whom no loan sale was reported at the time of the loan sale for the borrowers in our sample. This matched sample was constructed on the basis of industry and size matching as described by Barber and Lyons (1997). ${ }^{9}$

Table 6 examines the financial characteristics that affect a bank's decision to sell loans. Specifically, we took the sample of 29 firms that had their loans sold and the size

\footnotetext{
${ }^{9}$ The matching was done in the following way: For each firm that had its bank loan sold we generated a list of firms that not only had the same 2-digit SIC industry code classification but also had loans outstanding and reported total assets within a range of $70 \%$ to $130 \%$ of the total assets of the firm whose loans were sold. From this list we picked one firm at random. This procedure was repeated for each of the 29 firms in the original sample, thus producing an industry and size matched sample of 29 borrowing whose loans were not sold as a control group.
} 
and industry matched sample of 29 firms that did not experience a loan sale and for this total sample of 58 firms we estimated a probit model of the following form:

$$
\begin{aligned}
& \text { SELL_LOAN } \left.N_{i}=\beta_{0 i}+\beta_{1 i} \text { (Return on assets }\right)_{i}+\beta_{2 i} \text { (Total liabilities/ Total } \\
& \text { assets })_{i}+\beta_{3 i}(\text { Capital expenditure/ Total Assets })_{i}+\beta_{4 i} \text { (Standard deviation } \\
& \text { of stock returns } \left.)_{i}+\beta_{5 i} \text { (Cumulative stock returns }\right)_{i}+u_{i}
\end{aligned}
$$

As shown in Table 6 (looking first at the accounting variables) we find that the probability of a loan sale is higher if the borrower's profitability, as measured by its return on assets, is low. Further, firms that are relatively highly leveraged are more likely to have their loans sold. The negative and significant coefficient for investment intensity, as measured by the ratio of capital expenditure to total assets, implies that firms have a higher probability of having their loans sold if they are investing at a lower rate compared to industry (and size) matched firms. Table 6 also extends the probit model by incorporating two stock market-based variables. The first is the standard deviation of stock returns for each firm over a 150-day estimation period beginning 200 days before and ending 50 days before a loan sale. The second is the cumulative stock return for each firm measured over the same 150-day estimation period. On average, loan sale experiencing firms have a significantly lower cumulative stock return and higher standard deviation of returns in the period leading up to the announcement of a loan sale. The results in Table 6 show that the lower the returns and the higher the standard deviation of returns of a borrowing firm, the greater is the probability of its loan being sold.

These results are consistent with the financial trends that we observed in the loan sale firms' industry (in table 5). By and large these firms have higher leverage and a lower return on assets than the median firm. However, as they are far from being the weakest firms in their industry there appears to be no reason, ex-ante, to suspect a bankruptcy rate of $45 \%$ within 3 years of a loan sale. This suggests that the actual announcement of a loan sale by a bank is informative and indicative of a decrease in the future viability of the firm. 


\section{The effect of loan sales on bank stock returns}

The decision to sell a loan may also contain information about the quality of bank loan portfolios. Indeed, loan sales may be interpreted favorably by the market as a reflection that the average quality of a bank's remaining portfolio will improve -- given its incentive to sell-off, or divest, its poor quality loans. However, in selling such loans it has to assess the potential cost of such sales on its relationship with the borrower whose loan is sold, potential borrowers who may be concerned that their loans will be sold in the future $^{10}$, its reputation with investors who buy the loans sold by the bank (should they deteriorate further), as well as the fact that it might signal that the bank in general has exhibited poor management quality in its lending decisions and/or its capital position is weak. To examine the effects of a loan sale on a selling bank, we conducted an event study for those banks announcing the sale of loans. We are limited by the fact that Bank Letter news stories announcing loan sales do not always mention the identity of the selling bank. The quote below provides a typical loan sale announcement:

"A Musicland lender auctioned off \$11 million in bank debt late last week, with bids in the high 70s, according to market sources."

Bank Letter dated 1/27/1997

For the 107 total loan sale announcement originally collected from Bank Letter, we were able to identify the loan selling institution in 58 cases. Of these, 25 sale announcements were made by foreign financial institutions and 33 were made by US financial institutions. The lenders mentioned in these 33 US financial institution announcements were then matched to the CRSP daily stock price database. Two lenders did not have stock price information ${ }^{11}$ and two announcements involving Fleet bank were

\footnotetext{
${ }^{10}$ It is not unusual for borrowers to attempt curtailment of secondary trading in their loans, in an extreme case one borrower made it a part of the loan agreement by specifying eleven past lenders that it did not want its loan to be sold to. (See "Nextel Blackballs 11 Banks", Bank Letter, March 16, 1998)

${ }^{11}$ These were non-banking firms (Goldman Sachs and Heller Financial).
} 
made on the same day and thus were included as a single announcement, leaving us with 30 bank loan sale announcement dates. Finally, we removed the 3 loan sales made by investment banks leaving 27 US commercial bank loan sellers. ${ }^{12}$ The results of the event study on selling banks' returns are reported in Panel A of table 7. We also looked at the subset of first loan sale announcements involving the 29 borrowers that were examined in the "borrower"-related tests described in Tables 2 through 5. This subset yielded 11 clearly identifiable US bank lenders from the 29 first loan sales sub-sample. The loan sale announcement effects for these 11 banks are reported in Panel B of Table 7.

The results of Table 7 indicate that, on average, the sale of loans by banks do not appear to have any net (new) impact on the selling banks stock returns (i.e. there is no evidence of any net costs or benefits to the selling banks' shareholders). This result holds true for the whole sample where the bank seller could be identified (Panel A) as well as the sub-sample of first loan sales (Panel B).

Nevertheless, it is of interest to examine the characteristics that differentiate between those banks that engage in loan sales and those that do not, especially as some have argued that an important motivation for loan sales is to improve a bank's solvency position such as the bank's regulatory capital ratio (see for example Pennacchi, 1988). As discussed above, for the event study examining a bank's own share price reaction to a sale of a loan, we were able to identify 27 unique loan sale event dates. Since some banks announced multiple sales in the same year, these multiple loan selling banks were treated as a single observation in the same year. This resulted in a final sample of 19 distinct bank loan sale years. We obtained key financial characteristics for each of the selling banks for the year before the loan sale announcement from a variety of sources including Bank Compustat, Annual reports and 10-K filings. We then constructed a matched portfolio of 19 banks that did not announce a loan sale during the same year as

\footnotetext{
${ }^{12}$ Results remain unchanged if we include the three investment banks. The results for the sub sample of 3 Investment banks are similar to those reported for the sample of 27 banks.
} 
our sample of banks. Since banks involved in loan sales are usually large national banks, we constructed a list of all banks on Bank Compustat that reported total assets greater than $\$ 15$ billion in 1997, which generated a total of 41 US banking institutions. This list included 18 of the 19 sample banks that had sold loans for which we had stock return data. For each bank involved in a loan sale transaction we matched it with a bank that did not report a loan sale that year and which was closest in asset size to the loan-selling bank.

To examine the hypothesis as to whether a selling bank had different financial characteristics to a bank that did not sell loans we estimated a probit model of the following form:

SELL_LOAN $=f($ Bank Size, Bank Asset composition, Bank Liability composition, Bank Capital adequacy position, and Bank profitability characteristics)

where:

SELL_LOAN is equal to 1 if the bank sold a loan and 0 otherwise; and the other bank variables used in the probit tests are defined in Table 8.

The results reported in Table 8 show that banks involved in loan sales earn a significant amount of trading income, i.e., have a trading network and trading infrastructure in place that helps them conduct loan sales. Loan selling banks also have a larger proportion of their assets in Commercial and Industrial (C\&I) loans. The degree of capital reserves (measured by the size of a bank's Tier 1 capital ratio relative to its $4 \%$ tier-1 regulatory minimum) and its relative dependence on borrowed funds are not significantly related to the probability of a bank undertaking a loan sale.

The finding for the capital ratio is interesting, in that as discussed above, one potential motivation for loans sales is to enable banks to improve their solvency positions -- at 
least as measured by regulators. ${ }^{13}$ The finding of insignificance for the capital variable for our sample period, (1994-1998) in which most banks were profitable and capital ratios were at contemporary highs, suggests that capital constraints and regulatory pressures relating to loan sales were not important in this period.

\section{Summary and conclusion}

This is the first paper to evaluate empirically the effects of loan sales on both borrowers as well as bank stock returns. Using loan sales announcements reported in the publication Bank Letter we find evidence of a strong negative effect of loan sales by banks on borrowers' returns. This result is consistent with a strong certification effect of loan sales that may be reinforced by a reluctance of banks to sell loans for fears of harming existing and future customer relationships. Moreover, the sale of a loan appears to carry a signal to the capital market that is the mirror image of the findings of James (1987), Lummer and McConnell (1989) and others regarding the (positive) news effect of loan initiation and loan renewals. This result adds support to the view that banks play a special role in diffusing hitherto private information to outside investors. We also find that $45 \%$ of the firms whose loans are sold file for bankruptcy within 3 years of the announcement of a loan sale by their bank lender. While, cross-sectional tests confirmed that borrowers whose loans are sold are generally in a weaker financial and operating condition than a matched control group of firms whose loans were not sold, the sale of a loan appears to convey to the market additional (material) news about the relative degree of weakness of the borrowing firm whose loan is sold.

Finally, we examined the effects of loan sales on the selling bank itself, since the sale of a loan may convey new information to the market regarding the quality of a selling bank's loan portfolio as well as impacting among other things, its reputation and

\footnotetext{
${ }^{13} \mathrm{We}$ also conducted a robustness check where a bank's actual tier 1 capital ratio was used instead of its deviation from the $4 \%$ minimum ratio.
} 
relationships with other loan customers and investors. Interestingly, the sale of loans by banks carried no significant impact on a selling bank's stock return. Cross-sectional probit tests revealed that bank loan sales were made by banks that emphasized trading and had relatively large commercial and industrial loan portfolios. For our sample period, a bank's capital adequacy (or solvency) position did not appear to have a material effect on the probability of a bank selling its loans. 


\section{References}

Barber, B. and J. Lyon, 1997, Detecting abnormal operating performance: The empirical power and specification of test statistics, Journal of Financial Economics 41, 359-399.

Best, R. and H. Zhang, 1993, Alternative Information Sources and the Information Content of Bank Loans, Journal of Finance 48, 1507-1522.

Billet, M. T., M. J. Flannery, and J. A. Garfinkel, 1995, The effect of lender identity on a borrowing firm's equity return, Journal of Finance 50, 699-718.

Campbell, T. and W. Kracaw G., 1980, Information Production, market signaling, and the theory of intermediation, Journal of Finance 35, 863-882.

Dahiya, S., 2000 The Effect of Borrower's Financial Distress on the Lead Bank, Working Paper, Georgetown University.

Diamond, D. W., 1984, Financial intermediation and delegated monitoring, Review of Economics Studies 51, 393-414.

Dodd, P. and J. Warner, 1983, On corporate governance: A study of proxy contests, Journal of Financial Economics 11, 401-438.

Fama, E. 1985, What's different about banks, Journal of Monetary Economics 15, 29-36.

Gande, A., M. Puri, A. Saunders, I. Walter, Bank underwriting of debt securities: Modern evidence, Review of Financial Studies, 1997, 10(4), 1175-1202.

James, C., 1987, Some evidence of the uniqueness of bank loans, Journal of Financial Economics 19, 217-235.

James, C., 1988, The use of loan sales and standby letters of credit buy commercial banks, Journal of Monetary Economics 22, 395-422.

James, C. and D. C. Smith 2000, Are banks still special? New evidence on their role in the corporate capital-raising process, Journal of Applied Corporate Finance 13, 395-422.

Lummer, S., and J. McConnell, 1989, Further evidence on bank lending process and capital market response to bank loan agreements, Journal of Financial Economics 25, 5263.

Miller S., 1998, The development of the leveraged loan asset class. In Fabozzi, F. (Ed.), Bank Loans: Secondary Market and Portfolio Management, Frank J. Fabozzi Associates, New Hope, PA, pp. 1-23.

Pennacchi, G., 1988, Loan sales and cost of bank capital, Journal of Finance 43, 375-396. 
Puri, Manju, 1996, Commercial banks in investment banking: Conflict of interest or certification role?" Journal of Financial Economics, 1996, 40(3), 373-401.

Slovin, M. B., M. A. Shuska, and J. A. Polonchek, 1993, The value of bank durability: Borrowers as the bank stakeholders, Journal of Finance 48, 247-266. 


\section{TABLE 1}

\section{Cumulative Abnormal Returns for the firms on the announcement of sale of their loan by their bank}

Cumulative abnormal return (CARs) for 57 announcements of loan sale for the firms whose loans were sold by their lender. Panel A reports the CARs for all announcements. Panel B reports the CAR for the first time a firm's Loan is sold. Panel C reports the CAR for the second announcement of loan sale of a firm and Panel D reports the CAR for third announcement of loan sale of a firm.

\begin{tabular}{|c|c|c|}
\hline \multicolumn{3}{|c|}{$\begin{array}{l}\text { Panel A: Abnormal returns for all announcements of bank } \\
\qquad \begin{array}{c}\text { loan sale } \\
(\mathrm{N}=57)\end{array}\end{array}$} \\
\hline Event Window & CAR & t-statistic \\
\hline 11-day window $[-8,2]$ & $-8.555 \%$ & $-6.943 * * *$ \\
\hline 7-day window $[-4,2]$ & $-5.88700 \%$ & $-5.843 * * *$ \\
\hline 5 -day window $[-2,2]$ & $-4.777 \%$ & $-6.032 * * *$ \\
\hline 3 -day window $[-1,1]$ & $-4.5922 \%$ & $-8.886 * * *$ \\
\hline
\end{tabular}

\begin{tabular}{|c|c|c|}
\hline \multicolumn{3}{|c|}{$\begin{array}{l}\text { Panel B: Abnormal returns for the first loan sale } \\
\text { announcement loan sale was reported } \\
\qquad(\mathrm{N}=29)\end{array}$} \\
\hline Event Window & CAR & t-statistic \\
\hline 11-day window $[-8,2]$ & $-10.227 \%$ & $-5.669 * * *$ \\
\hline 7 -day window $[-4,2]$ & $-4.700 \%$ & $-2.592 * * *$ \\
\hline 5 -day window $[-2,2]$ & $-4.503 \%$ & $-3.579 * * *$ \\
\hline 3 -day window $[-1,1]$ & $-1.738 \%$ & $-3.656 * * *$ \\
\hline
\end{tabular}

Panel C: Abnormal returns for the second loan sale announcement loan sale was reported

\begin{tabular}{lll}
\multicolumn{3}{c}{$(\mathrm{N}=11)$} \\
\hline Event Window & CAR & t-statistic \\
11-day window [-8, 2] & $-6.5207 \%$ & $-2.463^{* * *}$ \\
7-day window [-4, 2] & $-5.001 \%$ & $-2.592^{* * *}$ \\
5-day window [-2, 2] & $-3.242 \%$ & $-2.223^{* *}$ \\
3-day window [-1, $]$ & $-5.725 \%$ & $-4.250^{* * *}$ \\
\hline
\end{tabular}




\begin{tabular}{lll}
\hline \multicolumn{3}{c}{$\begin{array}{c}\text { Panel D: Abnormal returns for the third loan sale } \\
\text { announcement loan sale was reported } \\
\end{array}$} \\
& CAR & \\
\hline Event Window & t-statistic \\
11-day window $[-8,2]$ & $-4.371 \%$ & -1.231 \\
7-day window [-4, 2] & $-4.761 \%$ & $-1.686^{*}$ \\
5-day window [-2, 2] & $-2.253 \%$ & -0.8396 \\
3-day window [-1, 1] & $-3.771 \%$ & $-1.829^{*}$ \\
\hline
\end{tabular}

*** Significant at $1 \%$ level, ** Significant at 5\% level,

* Significant at $10 \%$ level 
TABLE 2

\section{Cumulative Abnormal Returns for the firms on the announcement of sale of their loan by their bank}

Cumulative abnormal return (CARs) for 29 firms around the date of first announcement of sale of their loan by their lender. The CARs are calculated using the Center for Research in Security Prices (CRSP) database.

\begin{tabular}{|c|c|c|}
\hline \multicolumn{3}{|c|}{$\begin{array}{l}\text { Panel A: Abnormal returns for the firms for which a } \\
\text { bank loan sale was reported } \\
\qquad(\mathrm{N}=29)\end{array}$} \\
\hline Event Window & CAR & t-statistic \\
\hline 11-day window $[-8,2]$ & $-10.227 \%$ & $-5.669 * * *$ \\
\hline 7 -day window $[-4,2]$ & $-4.700 \%$ & $-2.592 * * *$ \\
\hline 5-day window $[-2,2]$ & $-4.503 \%$ & $-3.579 * * *$ \\
\hline 3-day window $[-1,1]$ & $-1.738 \%$ & $-3.656 * * *$ \\
\hline
\end{tabular}

*** Significant at $1 \%$ level, ** Significant at 5\% level,

* Significant at $10 \%$ level 
TABLE 3

Post - loan sale period incidence of financial distress for the sample of 29 firms for which an out standing bank loan was sold in the secondary market between January 1994 and December 1998

The information on filing for Chapter 11 is obtained from Bankruptcy Datasource and Dow Jones News Retrieval Services.

\begin{tabular}{|c|c|c|c|c|}
\hline $\begin{array}{l}\text { Incidence of } \\
\text { Chapter } 11 \\
\text { filing }\end{array}$ & $\begin{array}{l}\text { Less then } 12 \\
\text { months after } \\
\text { the loan sale } \\
\text { announcement }\end{array}$ & $\begin{array}{l}12 \text { months to } \\
24 \text { months } \\
\text { after the loan } \\
\text { sale } \\
\text { announcement }\end{array}$ & $\begin{array}{l}24 \text { months to } \\
36 \text { months } \\
\text { after the loan } \\
\text { sale } \\
\text { announcement }\end{array}$ & $\begin{array}{l}\text { More than } 36 \\
\text { months after } \\
\text { the loan sale } \\
\text { announcement }\end{array}$ \\
\hline $\begin{array}{l}\text { Number of } \\
\text { firms (for } \\
\text { which financial } \\
\text { data is } \\
\text { available) }\end{array}$ & 24 & 18 & 11 & 2 \\
\hline $\begin{array}{l}\text { Number of } \\
\text { firms filing for } \\
\text { Chapter } 11 \text { (\% } \\
\text { of sample) }\end{array}$ & $\begin{array}{c}8 \\
(28 \%)\end{array}$ & $\begin{array}{c}3 \\
(10 \%)\end{array}$ & $\begin{array}{c}2 \\
(7 \%)\end{array}$ & $\begin{array}{c}0 \\
(0 \%)\end{array}$ \\
\hline
\end{tabular}




\section{TABLE 4}

\section{Industry adjusted performance characteristics for the sample of 29 firms for which an out standing bank loan was sold in the secondary market between January 1994 and December 1998}

The financial information is for the last fiscal year prior to the year in which the loan sale took place and is obtained from Compustat. The table provides the financial characteristics for the 29 firms for which an announcement of loan sale is made. The ratios are reported on industry-adjusted basis, which is calculated as the difference between the relevant ratio (e.g. return on assets) of the sample firm and the median ratio (e.g. return on assets) for those firms operating in the same 2-digit SIC code as the sample firm. Return on assets is defined as the ratio of EBITDA to total assets. Investment intensity is the ratio of the capital expenditure to the total assets. Total leverage is the ratio of the sum of long term debt and current liabilities to the total assets. Also reported are the $t$ - statistic and $z$ - statistic for the null hypothesis that the mean and median are equal to zero.

\begin{tabular}{lllll}
\hline & $\begin{array}{c}\text { Industry adjusted } \\
\text { Mean }\end{array}$ & $\mathrm{t}$ - statistic & $\begin{array}{c}\text { Industry adjusted } \\
\text { Median }\end{array}$ & $\mathrm{z}$ - statistic \\
& & & & \\
\hline Return on Assets & -0.019 & $-1.880^{*}$ & -0.016 & $-1.806^{*}$ \\
Investment Intensity & -0.010 & -1.318 & -0.011 & -1.611 \\
Total Leverage & 0.135 & $3.802^{* * *}$ & 0.156 & $3.189^{* * *}$ \\
\hline
\end{tabular}

$* * *, * *, *$ Denotes mean (medians) significantly different from zero based on t-test (twotailed Wilcoxon signed rank test) at the $1 \%, 5 \%$ and $10 \%$ level respectively 


\section{TABLE 5}

\section{Within industry distribution of selected financial characteristics for the sample of 29 firms for which an out standing bank loan was sold in the secondary market between January 1994 and December 1998}

For each firm in the sample financial data is gathered for all firms with the same 2-digit SIC code in Compustat for the year before the year of sale. The relevant financial ratio is calculated for every firm in that industry to get the distribution of the ratio and to determine in which quartile the sample firms lies. Quartile 1 is the bottom $25 \%$ of the industry, Quartile 2 is the bottom $25 \%$ to $50 \%$ of the industry, Quartile 3 is the top 50\% to $75 \%$ of the industry and Quartile 4 is the top $25 \%$ of the industry. Return on assets is defined as the ratio of EBITDA to total assets. Investment intensity is the ratio of the capital expenditure to the total assets. Total leverage is the ratio of the sum of long term debt and current liabilities to the total assets. The above data is obtained from Compustat. The percentage of firms of the total sample in each category is given in parentheses.

\begin{tabular}{lcccc}
\hline Industry Quartile & Quartile 1 & Quartile 2 & Quartile 3 & Quartile 4 \\
\hline Return on Assets & 3 & 16 & 7 & 3 \\
& $(10.3 \%)$ & $(55.2 \%)$ & $(24.2 \%)$ & $(10.3 \%)$ \\
Investment Intensity & 9 & 12 & 3 & 5 \\
& $(31.4 \%)$ & $(41.4 \%)$ & $(10.3 \%)$ & $(7.2 \%)$ \\
Total Leverage & 3 & 2 & 9 & 15 \\
& $(10.3 \%)$ & $(6.9 \%)$ & $(31.0 \%)$ & $(51.8 \%)$ \\
\hline
\end{tabular}


TABLE 6

\section{Probit model for determinants of sale of a loan by the bank}

This table provides estimate of probit model governing the decision of a bank to sell a loan. The dependent variable SELL_LOAN ${ }_{i}$ which takes the value 1 for 29 firms that had their blank loans sold and 0 for the industry and size matched sample of 29 firms where no loan sale took place. Return on assets is defined as the ratio of EBITDA to total assets. Investment intensity is the ratio of the capital expenditure to the total assets. Total leverage is the ratio of the sum of long term debt and current liabilities to the total assets. Standard Deviation is the standard deviation of the daily returns of the firm during the period of 150 days starting 200 days before the loan sale event and up to 50 days before the loan sale. Estimation period return is the continuously compounded return for the same estimation period.

\begin{tabular}{|c|c|c|c|c|c|c|}
\hline & Coefficient & t-statistic & Coefficient & t-statistic & Coefficient & t-statistic \\
\hline Constant & -0.044 & -0.062 & -1.204 & -1.365 & -.0980 & -0.136 \\
\hline $\begin{array}{l}\text { Return on } \\
\text { Assets }\end{array}$ & -6.192 & $-2.216 * *$ & -4.319 & -1.475 & -6.119 & $-2.169 * *$ \\
\hline $\begin{array}{l}\text { Total } \\
\text { Leverage }\end{array}$ & 2.356 & $2.344 * *$ & 2.488 & $2.459 * *$ & 2.176 & $2.112 * *$ \\
\hline $\begin{array}{l}\text { Investment } \\
\text { Intensity }\end{array}$ & -9.297 & $-2.441 * *$ & -7.332 & $-2.011 * *$ & -6.628 & $-2.305^{* *}$ \\
\hline $\begin{array}{l}\text { Standard } \\
\text { Deviation }\end{array}$ & & & 26.427 & $1.696^{*}$ & & \\
\hline $\begin{array}{l}\text { Estimation } \\
\text { period } \\
\text { return }\end{array}$ & & & & & -1.504 & $-2.838 * * *$ \\
\hline Sample Size & 58 & & 58 & & 58 & \\
\hline Pseudo $\mathrm{R}^{2}$ & 0.24 & & 0.30 & & 0.32 & \\
\hline
\end{tabular}




\section{TABLE 7}

\section{Cumulative Abnormal Returns for the Banks on the announcement of sale of their loan}

In Panel A we report the Cumulative abnormal return (CARs) for 27 loan sale announcements by US banks. Panel B focuses on the lenders to the 29 firms studied in tables 1 through 6 whose loans were sold. It presents the Cumulative abnormal return (CARs) for 11 loan sale announcements by US banks for these borrowers. The CARs are calculated using the Center for Research in Security Prices (CRSP) database.

\begin{tabular}{lcl}
\hline \multicolumn{3}{c}{$\begin{array}{c}\text { Panel A: Abnormal returns for the Banks } \\
\text { (All announcements) } \\
(\mathrm{N}=27)\end{array}$} \\
\hline Event Window & CAR & t-statistic \\
11-day window [-8, 2] & $-0.0121 \%$ & 0.027 \\
7-day window [-4, 2] & $-0.0948 \%$ & -0.096 \\
5-day window [-2, 2] & $-0.0504 \%$ & -0.112 \\
3-day window [-1, 1] & $0.5940 \%$ & 1.4174 \\
\hline
\end{tabular}

Panel B: Abnormal returns for the Banks of 29

firms studied earlier

\begin{tabular}{lll}
\multicolumn{3}{c}{$(\mathrm{N}=11)$} \\
\hline Event Window & $\mathrm{CAR}$ & t-statistic \\
11-day window [-8, 2] & $0.7146 \%$ & 0.626 \\
7-day window [-4, 2] & $0.6572 \%$ & 0.702 \\
5-day window [-2, 2] & $0.8272 \%$ & 0.966 \\
3-day window [-1, 1] & $0.9539 \%$ & 1.389 \\
\hline
\end{tabular}

*** Significant at $1 \%$ level, $* *$ Significant at $5 \%$ level, $*$ Significant at $10 \%$ level 
TABLE 8

\section{Probit model for determinants of sale of a loan by the bank}

This table provides estimate of probit model governing the decision of a bank to sell a loan. The dependent variable SELL_LOAN takes the value 1 for the 19 banks that sold loans and 0 for the sample of 19 banks that did not sell any loans.

\begin{tabular}{|c|c|c|c|c|}
\hline & Coefficient & t-statistic & Coefficient & t-statistic \\
\hline Constant & -23.233 & $-2.282 * *$ & -27.121 & $-2.787 * * *$ \\
\hline Log (Total Asset) & 1.719 & $2.175 * *$ & 1.894 & $2.652 * * *$ \\
\hline $\begin{array}{l}\text { Commercial \& Industrial } \\
\text { Loans/Total Assets }\end{array}$ & 15.803 & $2.232 * *$ & 17.626 & $2.666 * * *$ \\
\hline Trading Income/Total Assets & 200.686 & $2.867 * * *$ & 232.72 & $2.799 * * *$ \\
\hline Net Income/Total Assets & & & 82.440 & 0.762 \\
\hline $\begin{array}{l}\text { Demand Deposits/Total } \\
\text { Assets }\end{array}$ & & & 2.025 & 0.217 \\
\hline $\begin{array}{l}\text { Federal Funds Purchased and } \\
\text { Repos sold/Total Assets }\end{array}$ & & & 0.972 & 0.085 \\
\hline Tier 1 Capital ratio $-4 \%$ & & & 0.107 & 0.328 \\
\hline $\begin{array}{l}\text { Reserves for bad loans/Total } \\
\text { Assets }\end{array}$ & & & -32.599 & -0.293 \\
\hline Sample Size & 36 & & 35 & \\
\hline Pseudo $\mathrm{R}^{2}$ & 0.51 & & 0.53 & \\
\hline
\end{tabular}

